\title{
Effect of zinc on the fracture behavior of galvanized steel/6061 aluminum alloy by laser brazing
}

\author{
Peilei Zhang ${ }^{\mathrm{a}, \mathrm{b} *}$, Haichuan $\mathrm{Shi}^{\mathrm{a}, \mathrm{b}}$, Yingtao Tian ${ }^{\mathrm{c} *}$, Zhishui Yu ${ }^{\mathrm{a}, \mathrm{b}}$, Di Wu ${ }^{\mathrm{a}, \mathrm{b}}$ \\ ${ }^{\text {a }}$ School of Materials Engineering, Shanghai University of Engineering Science, Shanghai 201620, China \\ ${ }^{\mathrm{b}}$ Shanghai Collaborative Innovation Center of Laser of Manufacturing Technology, Shanghai 201620, China \\ ${ }^{\mathrm{c}}$ Department of Engineering, Lancaster University, Bailrigg, Lancaster, LA1 4YW, United Kingdom
}

\begin{abstract}
The galvanized steel with thickness of $2 \mathrm{~mm}$ was joined to 6061 with thickness of $2 \mathrm{~mm}$ by laser fusion brazing process. The filler wire was $\mathrm{AlSi}_{5}$ and wire feed speeds were 2.8, 3.0, and $3.2 \mathrm{~m} / \mathrm{min}$, respectively. Microstructure and mechanical properties of the joints were investigated. The $\mathrm{Zn}$-rich zone formed in the area of the seam toe of was analyzed by means of optical microscope, scanning electron microscope and energy dispersive spectroscopy. Meanwhile, the $\mathrm{Fe}_{2} \mathrm{Al}_{5} \mathrm{Zn}_{0.4 p h a s e}, \mathrm{Fe}(\mathrm{Al}, \mathrm{Si})_{0.5}$ and $\mathrm{Fe}(\mathrm{Al}, \mathrm{Si})_{0.7}$ was found at the galvanized steel/brazed metal interface along the weld seam. According to tensile test, the strength of the joints were $31.6 \mathrm{MPa}$ (wire feed speed is $2.8 \mathrm{~m} / \mathrm{min}), 61.4 \mathrm{MPa}(3.0 \mathrm{~m} / \mathrm{min})$ and $70.4 \mathrm{MPa}(3.5 \mathrm{~m} / \mathrm{min})$, the failure occurred in interfacial layer at the bottom of the joint.
\end{abstract}

Keywords: Laser brazing; Galvanized steel; Aluminum alloy; Evaporation; Fracture behavior

\section{Introduction}

In auto industries, shipbuilding and aircraft construction, lightweight aluminum alloy and steel hybrid structure can significantly reduce fuel consumption and decrease air pollution [1].Aluminum alloy has many virtues, such as its low density, good corrosion resistance, excellent workability and machinability [2]. Therefore, steel-steel components have been replaced by aluminum-steel hybrid structures. A great of researches on joining aluminum to steel have been carried on to satisfy the necessities of many industrial applications. However, the differences of thermal conductivity, coefficient of linear expansion, between aluminum and steel bring difficulties by fusion welding. Because the density of aluminum is smaller than steel, thus, liquid

\footnotetext{
* Corresponding authors: Dr. Peilei Zhang (peilei@sues.edu.cn) and Dr. Yingtao Tian (y.tian12@lancaster.ac.uk).
} 
aluminum can float on the surface of steel in fusion welding process which has difficulty in forming reliable joints [3]. In the fusion welding process, the main problems are the generation of pores, cracks, and thermal stresses which severely affect the properties of the welded joints. If the welding process under the improper protection, aluminum is easy to be oxidized which lead to generate $\mathrm{Al}_{2} \mathrm{O}_{3}$ with high melting point which lead to slag in weld, incomplete fusion and other defects [4]. Many approaches have been made to join aluminum to steel in recent years [5]. Such as friction welding, explosion welding [6], resistance welding [7], and ultrasonic welding [8], have been taken, but these processes are suitable for certain weld joint types, so their application was limited.

Cold metal transfer (CMT) was also used to join aluminum to steel in recently [9-12]. But, because of its low heat input, CMT was available to join thin plates and the strength of the joints are limited. Recently, laser brazing has been explored as an innovative joining method to join sheets of dissimilar materials [13]. This method takes benefit of the variance in melting point of base materials. In case of Aluminum/steel dissimilar metal joining, laser beam melts the filler wire and aluminum sheet locally; the molten metal flows, spreads and wets the steel sheet forming a leak-proof brazed joint [14]. Laser weld-brazing offers industrially acceptable benefits such as high production rate, flexibility in operation and automation and hence, is a preferred process for dissimilar metal (aluminum-steel) joining [14]. Laser welding has many virtues, such as high welding speed, high energy density, small heat-affected zones, low distortion, and high levels of automation. In addition, laser welding can effectively control the growth of brittle $\mathrm{Fe}-\mathrm{Al}$ intermetallic compounds, offers great potential for further development [15]. P. Peyre et al. [16] used laser-induced reactive wetting to join an aluminum alloy to steel and found there were pores by zinc vaporization in the fusion zone and presence of cracks due to $\mathrm{Zn}$ local segregation. It was also found that the formation of low melting point $\mathrm{Al}-\mathrm{Zn}$ compounds at inter-dendritic spaces increase cracking susceptibility inside aluminum melt pool. Laser fusion-brazing with filler metal was used to join aluminum to steel.

Laser fusion-brazing combines the advantages of fusion welding and brazing by utilizing fusion welding on the aluminum side and brazing on the steel side [17]. Because the filler and aluminum were melted but steel was not leading to low heat input that could effectively decrease the formation of intermetallic phases and reduce the thermal stress in the joint [18]. M. Gatzen et 
al. [19] used laser brazing and welding and found that thin zinc layers can have an effect on the heat transfer during bead-on-plate brazing could be a significant transfer of latent heat to melt and evaporate the zinc-coating. Thicker coatings could therefore result in higher amounts of evaporating zinc, which in turn result in quicker removal of heat from the aluminum melt. A great amount of laser fusion welding results show that the zinc coating layer can act as flux to enhance wetting behavior and increase the joint strength [20]. In the laser welding-brazing of dissimilar metals, the weld formation, IMC (intermetallic compound) component and IMC morphology had great influence on the final mechanical properties [21]. Yuan et al. [22] proposed that smaller wetting ratio (the ratio between wetting length and angle) and newly formed porosity would reduce the bonding strength of the laser welded-brazed $\mathrm{Al} /$ steel joint. However, the approach on the fracture behavior of zinc-rich zone in aluminum with galvanized steel by laser fusion-brazing is not enough to understand.

The purpose of this study is to analyze the fracture behavior of zinc-rich zone in joint of the 6061 aluminum and zinc coated steel. The laser fusion brazing experiments with the AlSi5 filler, the laser welding of aluminum to non-galvanized steel and laser welding of aluminum to galvanized steel are performed carefully.

\section{Experimental procedures}

\subsection{Materials and filler metals}

Materials used are 6061 aluminum alloy (T6) and galvanized steel plates of $2.0 \mathrm{~mm}$ thickness. The thickness of $\mathrm{Zn}$ coating on the steel is $30 \mu \mathrm{m}$. The filler metal is AlSi5 with a diameter of 1.2 $\mathrm{mm}$. The chemical compositions of base materials and filler metals are shown in Table 1.

\subsection{Laser welding-brazing process}

The laser source is a fiber laser machine of IPG5000. The diameter of fiber of laser is $200 \mu \mathrm{m}$ and the diameter of laser beam spot on the plate is $0.4 \mathrm{~mm}$. The KUKA robot was used to grasp the laser head. Though the welding torch to feed the wire, the laser beam vertically transmitted on the wire and the work piece surface which can be seen in Fig. 1 and Fig. 2. All plates were cut into the size of $150 \mathrm{~mm} \times 50 \mathrm{~mm} \times 2 \mathrm{~mm}$, the surface was cleaned by abrasive paper and acetone before brazing. A laser fusion-brazing was used and the welding parameters were selected as $3000 \mathrm{~W}$ with the defocusing amount was $-2 \mathrm{~mm}$, the welding speed is $7 \mathrm{~mm} / \mathrm{s}$, the wire feeding speed is chosen as $2.8 \mathrm{~m} / \mathrm{min}$ (sample A) , $3.0 \mathrm{~m} / \mathrm{min}$ (sample B) and $3.5 \mathrm{~m} / \mathrm{min}$ (sample C) 
separately.

\subsection{Analysis methods}

After welding, metallographic specimens of typical cross-section of the welds were cut and then the specimens were polished by metallographic sandpapers of 150, 400, 600, 800, 1000, 1200 $\mathrm{SiC}$ grades. The solution ( $4 \mathrm{~mL} \mathrm{HNO} 3+96 \mathrm{~mL} \mathrm{CH} 3 \mathrm{CH} 2 \mathrm{OH},(5 \mathrm{~mL} \mathrm{HF}+95 \mathrm{~mL} \mathrm{H} 2 \mathrm{O})$ were used to etch the aluminum side and galvanized steel side of the metallographic specimens to reveal the general microstructure of the joints. The metallographic specimens were observed by optical microscope (OM), scanning electron microscope (SEM) and energy dispersive spectroscopy (EDS). X-ray diffraction was used for phase analysis. The tensile specimens were cut from each weld to evaluate the mechanical property of the joints. The microhardness test was carried out with a load of $0.5 \mathrm{~N}$ and loading time of $10 \mathrm{~s}$. In the tensile test, a load velocity of $2 \mathrm{~mm} / \mathrm{min}$ was employed.

\section{Results and discussion}

\subsection{Macrostructure and appearance of joints}

Fig. 3 shows appearances of the joints between aluminum and galvanized steel sheets made by different wire feeding speeds. The surface of welding seam was not smooth and satiation. There are some sink and slag. The zinc vapor leads to the sink in the surface of the weld seam. Due to the melted metal which is close to the base metal of aluminum and galvanized steel solidified firstly, there were some oxides on the surface of the weld seam, therefore, a line can be seen on the surface of the seam when the solidification was finished. For sample A, there are a lot of sags on the surface of the welding seam. The volatilization of the galvanized layer makes the wetting performance of the liquid aluminum on steel worse. For sample B, the wire feeding speed is higher so that there are more filling metals in the welding seam.

Fig.4 shows a typical cross-section of the joints. Higher wire feeding speed (Sample B) resulted in the increase of the contact angle between the steel and the weld metal. Meanwhile, the weld height of sample B is higher than sample A. This is mainly because that the wire feeding speed of sample A is small so that there are more heat input on the base metals. In addition, a special white zone at the tip of the weld seam can be found (designated by white arrows in Fig.4).

\subsection{Fusion zone}

The fusion zone is melted by filler metal and some aluminum alloy under the irradiation of 
laser beam. It can be known from Fig.5 (a) that the microstructure of the fusion zone is made up of gray celled crystals and black matter distributed along grain boundaries. For aluminum-silicon alloy, there are mainly some phases including $\alpha$-Al solid solution and aluminum-silicon eutectic alloy in the room temperature. As shown in Fig (b), the white net part is the $\alpha$-Al solid solution. The $\alpha$-Al solid solution is firstly formed during the process of cooling and solidification. When the temperature reaches 577 degrees, the Al-Si eutectic phases precipitated from the grain boundary of $\alpha$-Al. This is mainly because that the solid solubility of zinc in aluminum is greater than that of silicon in aluminum. Al-Zn eutectic structures may precipitated on the grain boundaries of $\alpha-\mathrm{Al}$ when temperature decreases to $381{ }^{\circ} \mathrm{C}$. Table 2 shows EDS analysis of different points in fusion zone. EDS analysis of the melted zone shows that the main components are $\mathrm{Al}$ and $\mathrm{Si}$, and it can be judged that the microstructure of the melted zone is $\alpha-\mathrm{Al}$ and the Al-Si eutectic structure.

\subsection{Intermetallic compound layer}

The zinc coating on the galvanized steel surface was seriously volatilized due to the laser irradiation. The interaction between laser and metals can be divided into three stages which can be seen in Fig. 6. Firstly, the molten aluminum was spread on the surface of the solid steel. Then the iron atoms dissolved in the molten aluminum. At last, the iron atoms which dissolved in the molten metals diffused to the aluminum. These stages have an important influence on the microstructure and properties of weld joints. The spread of liquid aluminum can effectively promote the dissolution and diffusion of iron atoms. The speed of forming intermetallic compound between aluminum and steel is fast. Diffusion process is dominated by reaction diffusion. The diffused atoms of $\mathrm{Al}$ and steel react with each other and form the FeAl supersaturated solid solution because that the diffusion coefficient of aluminum in the grain boundaries is much larger than that of other parts. When the components of supersaturated solid solution reach a certain degree, the $\mathrm{Fe}_{2} \mathrm{Al}_{5}$ phase nuclei formed firstly. The crystal structure of the $\mathrm{Fe}_{2} \mathrm{Al}_{5}$ phase is a trapezoid type, and there are more atomic vacancies along the $\mathrm{C}$ axis. As the diffusion process continued, the dense $\mathrm{FeAl}_{3}$ phase formed sequently. It shows that there is still a need to clarify the morphology and the growth kinetics of the intermetallic phases that form when $\mathrm{Fe}$ is in contact with liquid Al, both experimentally and theoretically [23]. The addition of Si to Al, which is known to decelerate reaction layer growth in interdiffusion experiments with $\mathrm{Al}$ melts, was found to accelerate the reaction layer growth in solid/semi-solid interdiffusion experiments [24]. So the 
amount of Si can be used to control the thickness of IMC layer [25].

The $\mathrm{Al}$ atoms in the weld seam are interacted with the $\mathrm{Fe}$ atoms in the galvanized steel of the base material to form $\mathrm{Fe}-\mathrm{Al}$ intermetallic compounds. It can be found that an intermetallic compound layer formed in the interface of brazing aluminum alloy and galvanized steel shown in Fig. 7. It is uneven near the aluminum side, indicating that the intermediate material grows on the edge of aluminum. The thickness of the intermetallic compound layer changes not only with the location but also with the varying wire feed speed. The thickness of the intermetallic metallic compounds (IMCs) in the center is greater than that on the edge of the seam. The Sample A, the maximum thickness of the IMC is about $2-4 \mu \mathrm{m}$, it is $8-10 \mu \mathrm{m}$ for Sample B and it is $8-12 \mu \mathrm{m}$ for sample C. The IMC formed at the interface between galvanized steel and brazed metal exhibits different shapes, the side near the steel appears smoother, and the side near the aluminum appears irregular and rough. It can be seen that two different phases are formed at the interface.

Fig. 8 represents the SEM image of IMC layer of welds and chemical composition obtained by $\mathrm{AlSi}_{5}$ filler wire with wire feed speed $3.0 \mathrm{~m} / \mathrm{min}$. In the central zone of weld, there were almost no zinc elements due to the evaporation in the process of welding. Many approaches indicated that the compounds of IMC were $\mathrm{Fe}_{2} \mathrm{Al}_{5}$ and $\mathrm{FeAl}_{3}$. Fig. 9 shows the X-ray diffraction pattern of the reaction layer shows. $\mathrm{Fe}_{2} \mathrm{Al}_{5} \mathrm{Zn}_{0.4}$ phase $、 \mathrm{Fe}_{3}(\mathrm{Al}, \mathrm{Si})_{0.5}$ phase $、 \mathrm{Fe}_{3}(\mathrm{Al}, \mathrm{Si})_{0.7}$ phase were formed at the interface of galvanized steel and brazed metal interface. $\mathrm{Fe}_{2} \mathrm{Al}_{5} \mathrm{Zn}_{0.4}$ phase was formed at the interface of steel and brazed metal which could be explained that $\mathrm{Fe}$ atoms were substituted by $\mathrm{Zn}$ atoms in the liquid aluminum in the formation of the IMCs. Due to the influence of unmelted iron, the slow diffusion speed of aluminum and iron atoms through the interface restricts the growth of intermetallic compounds. Distance of diffusion of $\mathrm{Al}$ and Fe atoms in the IMCs and growth time of IMCs can be expressed by [26] as follows:

$$
\mathrm{x}=\sqrt{D \mathrm{t}}
$$

Where $\chi(\mu \mathrm{m})$ is the thickness of IMC layer, $D\left(\mu \mathrm{m}^{2} \mathrm{~s}^{-1}\right)$ is the growth rate and $t(\mathrm{~s})$ is the growth time. The growth rate constant is related to temperature and can be expressed by Arrhenius relation. It can be concluded that the larger the thickness of intermetallic compound, the higher brazing temperature and longer brazing time are required.

\subsection{Zn -rich zone at weld tip}

At the beginning of welding, the zinc coating was melted by liquid aluminum because the 
melting point of aluminum is higher than that of zinc. Then, a part of liquid zinc atoms are dissolved in the molten aluminum to form an $\mathrm{Al}-\mathrm{Zn}$ liquid solution; other zinc atoms are pushed to the tip area of weld seam which leads to accumulate of zinc element and form the Zn-rich zone. Because the melting point of zinc is lower than aluminum, once the $\mathrm{Zn}$ gets into contact with the cold steel sheet, it rapidly solidified. Therefore, the concentration of zinc decreases sequentially in the direction of steel-brazing material and aluminum-brazing material. Fig. 10 shows the different morphology of the zinc-rich zone at different wire feed speeds. The presence of zinc not only reduces the surface tension of the molten solder, but also releases the mixing energy in the molten zone and promotes the spreading of the solder on the steel surface.

Higher wire feed speed may have a negative impact on wettability, because too fast wire feed speed will cause a large amount of zinc to evaporate, thereby reducing the wettability of the solder on the steel plate [27]. It should be noted that changes in the wire feed rate will cause changes in the heat input generated by laser brazing. The zinc coating on steel has different evaporation behavior at different wire feed speeds (the boiling point of zinc is about $907^{\circ} \mathrm{C}$ ). Figure 10 shows the two wire feed rates and the different wetting angles for the two morphologies in the zinc-rich region because the cooling rate is different at different locations of the joint. The tissue morphology of the zinc-rich region of sample A (Figure 10c) is a cell dendritic structure, and the tissue morphology of the zinc-rich region of sample B is also a cell dendritic structure, but it is solidified into different microstructures due to different cooling rates. The structure is smaller. In the area with low $\mathrm{Zn}$ content, $\mathrm{Zn}$ appears at the grain boundaries of $\mathrm{Al}$, and holes can be seen in Fig. 11 (a). The reason for these holes may be due to the escape of inert gas from the solder during the melting process.

Figure 11 shows the microstructure and element distribution of the zinc-rich zone at the weld toe of the joint analyzed by EPMA. The results show that the distribution of elements in the zinc-rich zone at the welding toe is $\mathrm{Al}, \mathrm{Si}, \mathrm{Zn}$. The element at the edge of the welding toe is mainly zinc. In the entire area of the zinc-rich zone, iron is much less than other elements, because the heat input at the welding toe is lower than the heat input at the middle of the fusion zone. The Fe element is difficult to diffuse from the center of the weld to the toe. Figure 12 shows that there is also a zinc concentration at the middle junction of the weld. It can be known that this position between aluminum and steel is also a stress concentration area. The gap between the steel plate 
and the aluminum plate is the main cause of stress concentration, and molten zinc is also easily concentrated in this area.

\subsection{Mechanical properties}

\subsubsection{Hardness measurements}

The microhardness of the welded joint section is shown in Figure 13. Figure 13 shows that the hardness of the interface between the filler metal and steel is higher than the hardness of the interface between the filler metal and aluminum alloy. The existence of the IMC layer causes this phenomenon. The hardness of the IMC layer can reach $425 \mathrm{HV}$, which is much higher than $70 \mathrm{HV}$ in the weld zone and $110 \mathrm{HV}$ in steel.

\subsubsection{Tensile test result}

Figure 14 shows a schematic diagram of the crack propagation path and final fracture in the laser brazed joint under tensile load. The result of the tensile test is that, when the wire feed rate is $2.8 \mathrm{~m} / \mathrm{min}$ (Simple A), the tensile strength of the welded joint is $31.6 \mathrm{MPa}$, the strength is 61.4 MPa with the wire feed speed $3.0 \mathrm{~m} / \mathrm{min}$ and $70.4 \mathrm{MPa}$ with $3.5 \mathrm{~m} / \mathrm{min}$. As shown in the figure, although the wire feed rate is different, the fracture occurs in the IMC layer at the bottom of the joint. The break mode of the joint has nothing to do with the wire feed speed. The accumulation of zinc at the location of stress concentration causes this region to fail easily in tensile tests [28], which is brittle fracture. In addition, the steel surface may not be cleaned well because grease dirt will reduce the wettability of the molten filler. The tensile strength of the IMC layer is lower than the heat affected zone of the aluminum alloy and the weld. The results show that even if the thickness of the IMC is less than $10 \mu \mathrm{m}$, brittle fracture occurs in the welded joint. In summary, the tensile strength of the lap joint is affected by the distribution of the IMC layer and the zinc element. The evaporation of zinc will affect the wettability of the solder to the steel, thereby making the welding process unstable. In addition, due to the high hardness and brittleness of the Fe-Al intermetallic compound, there are microcracks in the intermediate interface layer of the welded joint.

\section{Conclusions}

In this paper, the effect of zinc on the fracture behavior of joints under different wire feeding speeds in laser brazing of 6061 aluminum alloy and galvanized steel is studied in detail. The conclusions obtained are as follows:

1. The presence of zinc not only reduces the surface tension of the molten solder, but also releases 
the mixing energy in the molten zone and promotes the spreading of the solder on the steel surface. When the wire feeding speed is higher, the structure at the tip of the brazing layer is smaller, which is caused by the accelerated volatilization of zinc.

2. At the interface of galvanized steel and brazing metal, $\mathrm{Fe}_{2} \mathrm{Al}_{5} \mathrm{Zn}_{0.4}$ phase, $\mathrm{Fe}_{3}(\mathrm{Al}, \mathrm{Si}$ ) 0.5 phase and $\mathrm{Fe}_{3}(\mathrm{Al}, \mathrm{Si})_{0.7}$ phase were formed.

3. The tensile strength of the welded joint is $31.6 \mathrm{MPa}, 61.4 \mathrm{MPa}$ and $70.4 \mathrm{MPa}$ with the wire feed speed $2.8 \mathrm{~m} / \mathrm{min}, 3.0 \mathrm{~m} / \mathrm{min}$ and $3.5 \mathrm{~m} / \mathrm{min}$, respectively. Even if the thickness of the IMC is less than $10 \mu \mathrm{m}$, brittle fracture still occurs in the welded joint.

\section{Acknowledgements}

This research was supported by Natural Science Foundation of China (51805316, 51905333), Shanghai Sailing Program (19YF1418100), Shanghai Science and Technology Committee Innovation Grant (17JC1400600, 17JC1400601, 19511106400, 19511106402), Karamay Science and Technology Major Project (2018ZD002B), Aid for Xinjiang Science and Technology Project (2019E0235), Shanghai Local Colleges and Universities Capacity Building Special Plan Project (19030501300).

\section{References}

1. Haraga K (2000) Strength properties of aluminium/aluminium and aluminium/steel joints for light weighting of automotive body. Weld World 44:23-27

2. Li R, Wang M, Li Z, et al (2020) Developing a high-strength Al-Mg-Si-Sc-Zr alloy for selective laser melting: crack-inhibiting and multiple strengthening mechanisms. Acta Mater. https://doi.org/https://doi.org/10.1016/j.actamat.2020.03.060

3. Cheng J, Sun B, Ge Y, et al (2020) Effect of B/Si ratio on structure and properties of high-entropy glassy Fe25Co25Ni25(BxSi1-x)25 coating prepared by laser cladding. Surf Coatings Technol 402:126320. https://doi.org/https://doi.org/10.1016/j.surfcoat.2020.126320

4. Dong H, Yang L, Dong C, Kou S (2010) Arc joining of aluminum alloy to stainless steel with flux-cored Zn-based filler metal. Mater Sci Eng A 527:7151-7154. https://doi.org/10.1016/j.msea.2010.07.092

5. Habibnia M, Shakeri M, Nourouzi S, Givi MKB (2014) Microstructural and mechanical properties of friction stir welded $5050 \mathrm{Al}$ alloy and 304 stainless steel plates. Int J Adv Manuf Technol 76:819-829. https://doi.org/10.1007/s00170-014-6306-5

6. Tricarico L, Spina R (2010) Experimental investigation of laser beam welding of explosion-welded steel/aluminum structural transition joints. Mater Des 31:1981-1992. https://doi.org/10.1016/j.matdes.2009.10.032

7. Zhang W, Sun D, Han L, Liu D (2014) Interfacial microstructure and mechanical property of 
resistance spot welded joint of high strength steel and aluminium alloy with 4047 AlSi12 interlayer. Mater Des 57:186-194. https://doi.org/10.1016/j.matdes.2013.12.045

8. Haddadi F, Abu-Farha F (2015) Microstructural and mechanical performance of aluminium to steel high power ultrasonic spot welding. J Mater Process Technol 225:262-274. https://doi.org/10.1016/j.jmatprotec.2015.06.019

9. Cao R, Sun JH, Chen JH, Wang PC (2014) Cold metal transfer joining of aluminum AA6061-T6-to-galvanized boron steel. J Manuf Sci Eng Trans ASME 136:. https://doi.org/10.1115/1.4028012

10. Zhang P, Li G, Yan H, Tian Y (2020) Effect of positive/negative electrode ratio on cold metal transfer welding of 6061 aluminum alloy. Int J Adv Manuf Technol 106:1453-1464. https://doi.org/10.1007/s00170-019-04705-y

11. Peilei Z, Siyuan G, Zhengjun L, Zhishui Y (2019) Study on the hybrid laser-arc welding of 3 $\mathrm{mm}$ thick high-strength steel with high speed. Mater Res Express 6: https://doi.org/10.1088/2053-1591/aaef4e

12. Zhang P, Li M, Yan H, et al (2019) Microstructure evolution of Ni-Mo-Fe-Si quaternary metal silicide alloy composite coatings by laser cladding on pure Ni. J Alloys Compd 785:984-1000. https://doi.org/10.1016/j.jallcom.2019.01.191

13. Ma K, Yu Z, Zhang P, et al (2014) Study of influence of wire feeding speed on properties of laser brazing joint of zinc-coated steel. Zhongguo Jiguang/Chinese J Lasers 41: https://doi.org/10.3788/CJL201441.1003003

14. Narsimhachary D, Shariff SM, Padmanabham G, Basu A (2019) Influence of wire feed rate on mechanical and microstructure characteristics of aluminum to galvanized steel laser brazed joint. J Manuf Process 39:271-281. https://doi.org/10.1016/J.JMAPRO.2019.02.017

15. Gao M, Chen C, Mei S, et al (2014) Parameter optimization and mechanism of laser-arc hybrid welding of dissimilar Al alloy and stainless steel. Int J Adv Manuf Technol 74:199-208. https://doi.org/10.1007/s00170-014-5996-Z

16. Peyre P, Sierra G, Deschaux-Beaume F, et al (2007) Generation of aluminium-steel joints with laser-induced reactive wetting. Mater Sci Eng A 444:327-338.

https://doi.org/10.1016/j.msea.2006.09.111

17. Huang H, Zhang P, Yan H, et al (2021) Research on weld formation mechanism of laser-MIG arc hybrid welding with butt gap. Opt Laser Technol 133:106530. https://doi.org/10.1016/j.optlastec.2020.106530

18. Nie Y, Zhang P, Wu X, et al (2018) Rapid prototyping of 4043 Al-alloy parts by cold metal transfer. Sci Technol Weld Join 23:527-535. https://doi.org/10.1080/13621718.2018.1438236

19. Gatzen M, Radel T, Thomy C, Vollertsen F (2014) The role of zinc layer during wetting of aluminium on zinc-coated steel in laser brazing and welding. Phys Procedia 56:730-739. https://doi.org/10.1016/j.phpro.2014.08.080

20. Saida K, Ohnishi H, Nishimoto K (2010) Fluxless laser brazing of aluminium alloy to galvanized steel using a tandem beam - dissimilar laser brazing of aluminium alloy and steels. Weld Int 24:161-168. https://doi.org/10.1080/09507110902843065

21. Xia H, Tan C, Tian R, et al (2020) Influence of shielding gas on microstructure and mechanical properties of laser welded-brazed Al/steel lapped joint. J Manuf Process 54:347-358. https://doi.org/10.1016/J.JMAPRO.2020.03.030

22. Yuan R, Deng S, Cui H, et al (2019) Interface characterization and mechanical properties of 
dual beam laser welding-brazing Al/steel dissimilar metals. J Manuf Process 40:37-45.

https://doi.org/10.1016/J.JMAPRO.2019.03.005

23. Bouayad A, Gerometta C, Belkebir A, Ambari A (2003) Kinetic interactions between solid iron and molten aluminium. Mater Sci Eng A 363:53-61.

https://doi.org/10.1016/S0921-5093(03)00469-6

24. Springer H, Kostka A, Payton EJ, et al (2011) On the formation and growth of intermetallic phases during interdiffusion between low-carbon steel and aluminum alloys. Acta Mater 59:1586-1600. https://doi.org/10.1016/J.ACTAMAT.2010.11.023

25. Springer H, Kostka A, dos Santos JF, Raabe D (2011) Influence of intermetallic phases and Kirkendall-porosity on the mechanical properties of joints between steel and aluminium alloys. Mater Sci Eng A 528:4630-4642. https://doi.org/10.1016/J.MSEA.2011.02.057

26. Feng J, Xue S (2013) Growth behaviors of intermetallic compound layers in $\mathrm{Cu} / \mathrm{Al}$ joints brazed with Zn-22Al and Zn-22Al-0.05Ce filler metals. Mater Des 51:907-915. https://doi.org/10.1016/j.matdes.2013.04.069

27. Dharmendra C, Rao KP, Wilden J, Reich S (2011) Study on laser welding-brazing of zinc coated steel to aluminum alloy with a zinc based filler. Mater Sci Eng A 528:1497-1503. https://doi.org/10.1016/j.msea.2010.10.050

28. Yagati KP, Bathe RN, Rajulapati K V., et al (2014) Fluxless arc weld-brazing of aluminium alloy to steel. J Mater Process Technol 214:2949-2959.

https://doi.org/10.1016/j.jmatprotec.2014.06.017 